Article

\title{
The Influence of Sulfate on Anaerobic Ammonium Oxidation in a Sequencing Batch Reactor
}

\author{
Dominika Grubba * and Joanna Majtacz \\ Faculty of Civil and Environmental Engineering, Gdansk University of Technology, Narutowicza Street 11/12, \\ 80-233 Gdansk, Poland; joamajta@pg.edu.pl \\ * Correspondence: dominika.grubba@pg.edu.pl
}

Received: 15 September 2020; Accepted: 25 October 2020; Published: 26 October 2020

\begin{abstract}
Anaerobic ammonia-oxidizing bacteria have a more comprehensive metabolism than expected - there may be other electron acceptors that oxidize ammonium nitrogen under anaerobic conditions, in addition to the well-known nitrite nitrogen, one of which is sulfate in the sulfammox process. Sulfate-containing compounds are part of the medium for the anammox process, but their concentrations are not particularly high $\left(0.2 \mathrm{~g} \mathrm{MgSO}_{4} \cdot 7 \mathrm{H}_{2} \mathrm{O} / \mathrm{dm}^{3}\right.$ and $\left.0.00625 \mathrm{~g} \mathrm{FeSO} / \mathrm{dm}^{3}\right)$. They can react to some extent with influent ammonium nitrogen. In this work, tests were carried out in two sequencing batch reactors with granular sludge. The first reactor (R1) operated in a $6 \mathrm{~h}$ cycle, and the concentration of the inflowing sulfate was kept at $44 \mathrm{mg} / \mathrm{dm}^{3} \cdot \mathrm{d}$. The second reactor (R2) was operated until the 36th day in a $6 \mathrm{~h}$ cycle; the influencing concentration was $180 \mathrm{mg} \mathrm{SO}_{4}{ }^{2-} / \mathrm{dm}^{3} \cdot \mathrm{d}$ from the 37 th to 64 th day in a $3 \mathrm{~h}$ cycle, with an influencing concentration of $360 \mathrm{mg} \mathrm{SO}_{4}{ }^{2-} / \mathrm{dm}^{3} \cdot \mathrm{d}$; and from the 65 th to 90 th day, the reactor was operated again in a $6 \mathrm{~h}$ cycle with an influencing concentration of $180 \mathrm{mg} \mathrm{SO}_{4}{ }^{2-} / \mathrm{dm}^{3} \cdot \mathrm{d}$. Along with the increased share of sulfate, both the ammonium utilization rate and specific anammox activity showed an increasing trend. As soon as the sulfate dosage was reduced, the ammonium utilization rate and specific anammox activity values dropped. Therefore, it can be concluded that sulfate-containing compounds contribute to the efficiency and rate of the anammox process.
\end{abstract}

Keywords: sulfammox; anammox; sulfate; ammonium utilization rate; specific anammox activity

\section{Introduction}

Several industrial processes such as fermentation, tanning, landfill leachate production, paper production, pharmaceutical production and food processes produce wastewater containing high concentrations of sulfate $\left(\mathrm{SO}_{4}{ }^{2-}\right)$ and ammonium nitrogen $\left(\mathrm{NH}_{4}-\mathrm{N}\right)$ [1]. Such sewage requires treatment before discharge to the environment, as it is harmful to human life [2].

$\mathrm{SO}_{4}{ }^{2-}$ is conventionally removed by anaerobic processes by sulfate-reducing bacteria (SRB) [3,4], where $\mathrm{SO}_{4}{ }^{2-}$ is the final electron acceptor and organic carbon is the electron donor [5]. In contrast, the combined nitrification-denitrification processes are the main pathway responsible for the transformation of nitrogen $(\mathrm{N})$ compounds in wastewater treatment systems in which ammonia-oxidizing bacteria (AOB), nitrogen-oxidizing bacteria $(\mathrm{NOB})$ and heterotrophic bacteria are involved. The discovery of the anammox process shed new light on the nitrogen cycle. This biological process involves oxidizing ammonium nitrogen $\left(\mathrm{NH}_{4}-\mathrm{N}\right)$ under anoxic conditions to gaseous nitrogen $\left(\mathrm{N}_{2}\right)$, using nitrite nitrogen $\left(\mathrm{NO}_{2}-\mathrm{N}\right)$ as the electron acceptor, via anaerobic ammonia-oxidizing bacteria (AAOB). Accordingly, the removal of $\mathrm{SO}_{4}{ }^{2-}$ and $\mathrm{NH}_{4}-\mathrm{N}$ generally takes place in separate processes, as each purification step requires different bacterial groups and environmental conditions. This is associated with high costs due to the necessity of aeration, external carbon sources and excess sludge 
disposal [6]. However, to date, little is known about the ability of AAOB to use $\mathrm{SO}_{4}{ }^{2-}$ as an electron acceptor [6].

Fdz-Polanco et al. [7] described the reaction of the autotrophic anaerobic oxidation of $\mathrm{NH}_{4}-\mathrm{N}$ and deoxidation of $\mathrm{SO}_{4}{ }^{2-}$ in three Equations (1)-(3):

$$
\begin{gathered}
3 \mathrm{SO}_{4}{ }^{2-}+4 \mathrm{NH}_{4}{ }^{+} \rightarrow 4 \mathrm{NO}_{2}^{-}+3 \mathrm{~S}^{2-}+4 \mathrm{H}_{2} \mathrm{O}+8 \mathrm{H}^{+} \\
3 \mathrm{~S}^{2-}+2 \mathrm{NO}_{2}^{-}+8 \mathrm{H}^{+} \rightarrow \mathrm{N}_{2}+3 \mathrm{~S}^{0}+4 \mathrm{H}_{2} \mathrm{O} \\
2 \mathrm{NO}_{2}^{-}+2 \mathrm{NH}_{4}^{+} \rightarrow 2 \mathrm{~N}_{2}+4 \mathrm{H}_{2} \mathrm{O}
\end{gathered}
$$

At first, $\mathrm{NH}_{4}-\mathrm{N}$ is partially oxidized and deoxygenated by $\mathrm{SO}_{4}{ }^{2-}$ to produce $\mathrm{NO}_{2}-\mathrm{N}$ and sulfides $\left(\mathrm{S}^{2-}\right)$ (see reaction 1). Then, some of the $\mathrm{NO}_{2}-\mathrm{N}$ is reduced by $\mathrm{S}^{2-}$ in the sulfur-dependent autotrophic denitrification process and converted into $\mathrm{N}_{2}$ and elemental sulfur $\left(\mathrm{S}^{0}\right)$ (see reaction 2). Ultimately, the conventional anammox process follows (see reaction 3 ).

It turns out that AAOB's metabolism is more comprehensive than expected [8,9] and, in addition to the commonly known electron acceptor in the form of $\mathrm{NO}_{2}-\mathrm{N}$, there may be other electron acceptors that oxidize $\mathrm{NH}_{4}-\mathrm{N}$ under anaerobic conditions [10]. The process described in reactions 1-3 is called the sulfammox process (i.e., sulfate-reducing ammonium oxidation (SRAO)) [11]. The sulfammox process is a promising resource for wastewater treatment systems, because wastewater contains high amounts of sulfur compounds [12]. It can be represented in one reaction as follows [13] (4):

$$
\mathrm{SO}_{4}{ }^{2-}+2 \mathrm{NH}_{4}{ }^{+} \rightarrow \mathrm{S}^{0}+\mathrm{N}_{2}+4 \mathrm{H}_{2} \mathrm{O}
$$

Producing $\mathrm{N}_{2}$ and elemental sulfur $\left(\mathrm{S}^{0}\right)$ is desirable in wastewater treatment and for the recovery of resources. Moreover, the simultaneous removal of $\mathrm{SO}_{4}{ }^{2-}$ and $\mathrm{NH}_{4}-\mathrm{N}$ is more beneficial in terms of reducing costs than the separate removal of these pollutants [14]. The discovery of the sulfammox process suggests that the interrelationships between the $\mathrm{N}$ and $\mathrm{S}$ biochemical cycles is far more complex than previously assumed.

It is worth noting that the process of sulfur-dependent autotrophic denitrification has been described as a component of sulfammox. It is an autotrophic process in which chemotrophic sulfur-oxidizing bacteria ( $\mathrm{SOB})$ oxidize reduced sulfur compounds such as $\mathrm{S}^{2-}, \mathrm{S}^{0}$, sulfite $\left(\mathrm{SO}_{3}{ }^{2-}\right)$ or thiosulfate $\left(\mathrm{S}_{2} \mathrm{O}_{3}{ }^{2-}\right)$ as electron donors with $\mathrm{NO}_{3}-\mathrm{N}$ or $\mathrm{NO}_{2}-\mathrm{N}$ as electron acceptors [15-18]. Then, $\mathrm{SO}_{4}{ }^{2-}$ or $\mathrm{S}^{0}$ is formed depending on the sulfur-to-nitrogen ratio [2]. $\mathrm{S}^{2-}$ produced by sulfate-reducing bacteria can also be used as an electron donor for sulfur denitrification [19].

Due to the complex transformations of sulfur and nitrogen in anaerobic conditions, it is worth considering the effect of $\mathrm{SO}_{4}{ }^{2-}$ on anaerobic $\mathrm{NH}_{4}-\mathrm{N}$ oxidation. The sulfammox process can run independently without the addition of $\mathrm{NO}_{2}-\mathrm{N}$ or in combination with the conventional $\left(\mathrm{NO}_{2}-\mathrm{N}_{\text {based }}\right)$ annamox process. Research on the sulfammox process was carried out in various configurations. At the beginning of the research, $\mathrm{SO}_{4}{ }^{2-}$ was used as an electron acceptor without the addition of $\mathrm{NO}_{2}-\mathrm{N}[9,11,20-23]$. Other studies started with a conventional anammox, with $\mathrm{NO}_{2}-\mathrm{N}$ as an electron acceptor, and replaced $\mathrm{NO}_{2}-\mathrm{N}$ with a new $\mathrm{SO}_{4}{ }^{2-}$ electron acceptor $[11,12,24]$. There are also reports in which $\mathrm{SO}_{4}{ }^{2-}$ was used simultaneously with $\mathrm{NO}_{2}-\mathrm{N}$ as an electron acceptor [25,26]. For example, Zhang et al. [25] and Wu et al. [26] showed a high degree of simultaneous removal of $\mathrm{NH}_{4}-\mathrm{N}$ and $\mathrm{SO}_{4}{ }^{2-}$, in the range of $92-99 \%$ and $53-60 \%$, respectively, when anammox and sulfammox reactions occurred simultaneously. Therefore, the research shows that combining the two processes can achieve an increase in the overall nitrogen removal efficiency.

To date, research work has focused mainly on the effect of increased proportions of $\mathrm{NH}_{4}-\mathrm{N}$ and $\mathrm{N} / \mathrm{S}$ ratio in relation to the sulfammox process $[10,20,21]$. The influence of increased proportions of $\mathrm{SO}_{4}{ }^{2-}$ on anaerobic $\mathrm{NH}_{4}-\mathrm{N}$ oxidation in the presence of $\mathrm{NO}_{2}-\mathrm{N}$ due to the reduced cycle time has yet to be described. The purpose of this study is to compare the operation of two sequencing batch reactors (SBR) with granular sludge: one operates under a constant load of $\mathrm{SO}_{4}{ }^{2-}$ and constant duration of the 
process cycle, and the other operates with an increased and variable load of $\mathrm{SO}_{4}{ }^{2-}$ in a variable cycle time. The process efficiency was compared by calculating the ammonia utilization rate (AUR) and the specific anammox activity (SAA). It is suspected that $\mathrm{SO}_{4}{ }^{2-}$ will increase the AUR and SAA as it will act as an additional electron acceptor in the anaerobic oxidation of $\mathrm{NH}_{4}-\mathrm{N}$.

\section{Materials and Methods}

\subsection{Laboratory-Scale Bioreactor}

The inoculated biomass originated from a full-scale side-stream deammonification system in Plettenberg, Germany.

The laboratory scale system used in this study consisted of two $4 \mathrm{dm}^{3}$ sequencing batch reactors (SBRs) laid out according to the scheme in Figure 1. The system was equipped with a thermostatic jacket maintaining a constant temperature in the range of -35 to $+200{ }^{\circ} \mathrm{C}$, with an accuracy of $\pm 0.1^{\circ} \mathrm{C}$. Each reactor was equipped with an electric stirrer with variable speed. In the main reactor, probes were placed to measure pH (Endress + Hauser EH CPS 471D-7211, Switzerland) and to measure dissolved oxygen (DO) (Endress + Hauser COS22D-10P3/O, Germany).

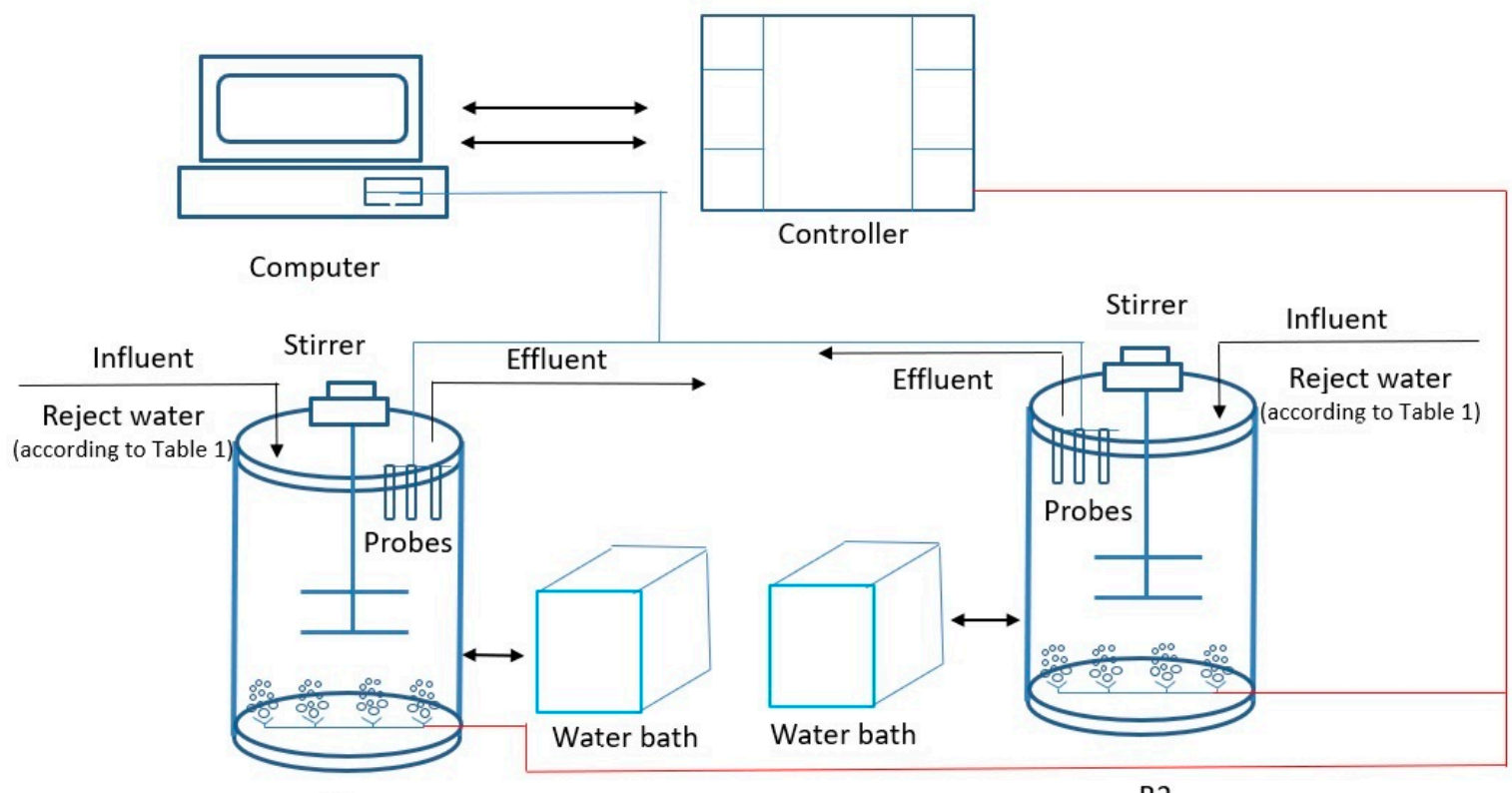

R1

$\mathrm{R} 2$

Figure 1. Laboratory-scale system for the anammox process.

All measured data were transmitted to the programmable logic controller (PLC) and used for control and regulation. Measurement data for archival and further use were sent to an application called Intouch'a.

\subsection{Operational Conditions of the Laboratory-Scale SBRs}

The tests were carried out continuously for 90 days. During the entire test period, the SBRs operated at a constant temperature of $30( \pm 1){ }^{\circ} \mathrm{C}$. The $\mathrm{pH}$ was maintained in the range of $7.5-7.8$ through the automatic addition of $4 \mathrm{M}$ sodium hydroxide $(\mathrm{NaOH})$. The DO concentration in unventilated SBRs did not exceed $0.2 \mathrm{mg} / \mathrm{dm}^{3}$, and SBRs were fed with synthetic substrate according to the method of Dapena-Mora et al. [27] and Table 1. 
Table 1. Number of cycles and concentrations of compounds in R1 and R2.

\begin{tabular}{|c|c|c|c|c|c|c|c|c|c|}
\hline \multirow{3}{*}{ Reactor } & \multirow{3}{*}{ Day } & \multirow{3}{*}{$\begin{array}{l}\text { Number of } \\
\text { Cycles } \\
\text { per Day }\end{array}$} & \multirow[t]{2}{*}{$\begin{array}{l}\text { Time of One } \\
\text { Cycle }\end{array}$} & \multicolumn{2}{|c|}{$\begin{array}{c}\mathrm{SO}_{4}{ }_{4}^{2-} \text { Concentration in } \\
\text { the Reactor }\end{array}$} & \multicolumn{2}{|c|}{$\begin{array}{c}\mathrm{NH}_{4}-\mathrm{N} \text { Concentration in } \\
\text { the Reactor }\end{array}$} & \multicolumn{2}{|c|}{$\begin{array}{c}\mathrm{NO}_{2}-\mathrm{N} \text { Concentration in the } \\
\text { Reactor }\end{array}$} \\
\hline & & & & per Cycle & per Day & per Cycle & per Day & per Cycle & per Day \\
\hline & & & (h) & $\left(\mathrm{mg} / \mathrm{dm}^{3}\right)$ & $\left(\mathrm{mg} /\left(\mathrm{dm}^{3} \cdot \mathrm{d}\right)\right)$ & $\left(\mathrm{mg} / \mathrm{dm}^{3}\right)$ & $\left(\mathrm{mg} /\left(\mathrm{dm}^{3} \cdot \mathrm{d}\right)\right)$ & $\left(\mathrm{mg} / \mathrm{dm}^{3}\right)$ & $\left(\mathrm{mg} /\left(\mathrm{dm}^{3} \cdot \mathrm{d}\right)\right)$ \\
\hline R1 & $0-90$ & 4 & 6 & 11 & 44 & 38 & 152 & 50 & 200 \\
\hline \multirow{3}{*}{ R2 } & $0-36$ & 4 & 6 & \multirow{3}{*}{45} & 180 & \multirow{3}{*}{38} & 152 & \multirow{3}{*}{50} & 200 \\
\hline & $37-64$ & 8 & 3 & & 360 & & 304 & & 400 \\
\hline & $65-90$ & 4 & 6 & & 180 & & 152 & & 200 \\
\hline
\end{tabular}

In each cycle, $2 \mathrm{dm}^{3}$ of supernatant water was withdrawn from both reactors and replaced with a new portion of the synthetic substrate. The most important ingredients-i.e., nitrite, ammonium and sulfate-were supplied in the form of $\mathrm{NH}_{4} \mathrm{Cl}, \mathrm{NaNO}_{2}$ and $\mathrm{MgSO}_{4}$, respectively.

\subsection{Analytical Methods}

The concentration of $\mathrm{NO}_{3}-\mathrm{N}, \mathrm{NO}_{2}-\mathrm{N}$ and $\mathrm{NH}_{4}-\mathrm{N}$ compounds was determined using a DR 3900 spectrophotometer using cuvette tests from Hach Lange $\mathrm{GmbH}$ (Dusseldorf, Germany) for analysis. The biomass concentrations were determined as a volatile suspended solids (VSS) fraction of the total suspended solids (TSS) in accordance with the standard methods [28]. The biomass-specific AUR, SAA and nitrate production rate (NPR) were determined based on the maximum slope of $\mathrm{NH}_{4}-\mathrm{N}$ consumption, $\mathrm{NH}_{4}-\mathrm{N}$ combined with $\mathrm{NO}_{2}-\mathrm{N}$ consumption and $\mathrm{NO}_{3}-\mathrm{N}$ production in the reaction phase divided into mixed liquor volatile suspended solids (MLVSS) concentrations, respectively. Throughout the operation period, the MLVSS value was $1750( \pm 50) \mathrm{mg} / \mathrm{dm}^{3}$ in R1 and $1900( \pm 50)$ $\mathrm{mg} / \mathrm{dm}^{3}$ in R2. AUR, SAA and NPR are given in units of $\mathrm{mg} \mathrm{N} / \mathrm{g}$ VSS.h to represent these rates in relation to the indicated MLVSS.

\section{Results and Discussion}

The efficiency of $\mathrm{NH}_{4}-\mathrm{N}$ oxidation in anaerobic conditions is influenced by anammox, sulfammox, heterotrophic and autotrophic (full and partial) denitrification processes. On the other hand, under aerobic conditions, the oxidation of $\mathrm{NH}_{4}-\mathrm{N}$ takes place in the process of nitrification or partial nitrification. In our studies, SBR controlled DO at a low level $\left(<0.2 \mathrm{mg} / \mathrm{dm}^{3}\right)$, and the lack of an added external carbon source prevented the occurrence of heterotrophic conditions. Accordingly, the only possible pathways for $\mathrm{NH}_{4}-\mathrm{N}$ oxidation were through anammox, sulfammox and sulfur-dependent autotrophic denitrification.

Previous studies describe the complete efficiency of $\mathrm{NH}_{4}-\mathrm{N}$ and $\mathrm{SO}_{4}{ }^{2-}$ removal as a combination of anammox, sulfammox, nitrification and denitrification $[10,11,20,26]$ or a result of anaerobic processes only [21,29] or of the sulfammox reaction only [30,31] (see Table 2). Moreover, it is worth noting that a few studies on the anaerobic oxidation of $\mathrm{NH}_{4}-\mathrm{N}$ in the presence of $\mathrm{SO}_{4}{ }^{2-}$ have been carried out with $\mathrm{NO}_{2}-\mathrm{N}[10,26]$. Some of them consisted of only replacing $\mathrm{NO}_{2}-\mathrm{N}$ with a new electron acceptor in the form of $\mathrm{SO}_{4}{ }^{2-}[11,31]$, yet the vast majority of the oxidation took place without $\mathrm{NO}_{2}-\mathrm{N}[9,11,20,21,23,29,30]$. 
Table 2. Concentrations of influent $\mathrm{NH}_{4}-\mathrm{N}$ and $\mathrm{SO}_{4}{ }^{2-}$ and the efficiency of their removal under anaerobic conditions. SRAO: sulfate-reducing ammonium oxidation; SRB: sulfate-reducing bacteria.

\begin{tabular}{|c|c|c|c|c|c|c|}
\hline Reactor & $\begin{array}{l}\text { Influent } \mathrm{NH}_{4}-\mathrm{N} \\
\left(\mathrm{mg} / \mathrm{dm}^{3}\right)\end{array}$ & $\begin{array}{l}\text { Influent } \mathrm{SO}_{4}{ }^{2-} \\
\left(\mathrm{mg} / \mathrm{dm}^{3}\right)\end{array}$ & $\begin{array}{l}\mathrm{NH}_{4}-\mathrm{N} \text { Removal } \\
\text { Efficiency (\%) }\end{array}$ & $\begin{array}{l}\mathrm{SO}_{4}^{2-} \text { Removal } \\
\text { Efficiency (\%) }\end{array}$ & Brief Characteristics & Reference \\
\hline $\begin{array}{l}\text { Combining system: Upflow } \\
\text { Anaerobic Sludye Blanket (UASB), } \\
\text { Anoxic/Oxic Reactor (A/O), } \\
\text { Anammox and Sulfammox Reactor } \\
\text { (ANAOR), Anaerobic Sequencing } \\
\text { Batch Reactor (ASBR) }\end{array}$ & $610-700$ & $1870-1920$ & ca. 98 & ca. 53 & $\begin{array}{c}\text { Reduction of } \mathrm{SO}_{4}{ }^{2-} \text { and } \mathrm{NH}_{4}-\mathrm{N} \text { was considered as a } \\
\text { combination of anammox, sulfammox, nitrification and } \\
\text { denitrification processes. }\end{array}$ & [26] \\
\hline \multirow{3}{*}{$\begin{array}{l}\text { Continuous Flow Stirred Tank } \\
\text { Reactor } \\
\text { (CFSTR) }\end{array}$} & 110 & $0-110$ & ca. 40 & ca. 0 & \multirow{3}{*}{$\begin{array}{l}\text { SRAO was considered as a combination of aerobic } \\
\text { ammonium oxidation, anammox and heterotrophic } \\
\text { sulfate reduction processes. }\end{array}$} & \multirow{3}{*}{ [11] } \\
\hline & 60 & 90 & ca. 30 & ca. 10 & & \\
\hline & 60 & 90 & ca. 55 & ca. 0 & & \\
\hline \multirow{4}{*}{$\begin{array}{l}\text { Self-Designed Circulating } \\
\text { Flowreactor } \\
\text { (SDCF) }\end{array}$} & 120 & 183 & ca. 30 & ca. 40 & \multirow{4}{*}{$\begin{array}{l}\text { These results showed that nitrogen was converted by } \\
\text { nitrification, denitrification and conventional anammox, } \\
\text { simultaneously with SRAO. The sulfur-based } \\
\text { autotrophic denitrification and denitificition in the } \\
\text { reactor were caused by the influent } \mathrm{NO}_{2}-\mathrm{N} \text {. }\end{array}$} & \multirow{4}{*}{ [10] } \\
\hline & 160 & 216 & ca. 55 & ca. 0 & & \\
\hline & 110 & 116 & ca. 75 & ca. 30 & & \\
\hline & 80 & 100 & ca. 100 & ca. 45 & & \\
\hline \multirow{3}{*}{$\begin{array}{l}\text { Self-Designed Circulating } \\
\text { Flowreactor } \\
\text { (SDCF) }\end{array}$} & 50 & 90 & ca. 40 & ca. 30 & \multirow{3}{*}{$\begin{array}{l}\text { Part of nitrogen was converted by } \\
\text { nitrification-denitrification and conventional } \\
\text { anammox, simultaneously with SRAO. }\end{array}$} & \multirow{3}{*}{ [20] } \\
\hline & 120 & 170 & ca. 90 & ca. 30 & & \\
\hline & 180 & 360 & ca. 20 & ca. 5 & & \\
\hline \multirow{3}{*}{$\begin{array}{l}\text { Expanded Granular Sludge Bed } \\
\text { (EGSB) }\end{array}$} & $166-666$ & \multirow{3}{*}{3600} & $40-58$ & $64-71$ & \multirow{3}{*}{$\begin{array}{l}\text { SRB and denitrifying bacteria were mainly responsible } \\
\text { for } \mathrm{SO}_{4}^{2-} \text { and nitrogen removal. }\end{array}$} & \multirow{3}{*}{ [21] } \\
\hline & $1000-2000$ & & $40-70$ & $66-82$ & & \\
\hline & $>3000$ & & $10-25$ & 28 & & \\
\hline $\begin{array}{l}\text { Anaerobic Sequencing Batch } \\
\text { Reactor } \\
\text { (ASBR) }\end{array}$ & 97 & 261 & ca. 88 & ca. 19 & $\begin{array}{l}\text { The presence of Planctomycetes revealed that } \\
\text { anammox was highly involved in } \mathrm{NH}_{4}-\mathrm{N} \text { removal, } \\
\text { even without } \mathrm{NO}_{2}-\mathrm{N} \text { in the feed. Other autotrophic } \\
\text { denitrifying bacteria, related to the species Paracoccus } \\
\text { Denitrificans, were also present. These bacteria utilize } \\
\mathrm{S}^{0} \text { as an electron donor, produce } \mathrm{SO}_{4}^{2-} \text { and } \\
\text { competitively use } \mathrm{NO}_{2}-\mathrm{N} \text { with anammox. }\end{array}$ & [29] \\
\hline $\begin{array}{l}\text { Expanded Bed Reactor } \\
\text { (EBR) }\end{array}$ & 229 & 163 & ca. 44 & 40 & $\begin{array}{c}\text { The reduction of } \mathrm{SO}_{4}{ }^{2-} \text { and } \mathrm{NH}_{4}-\mathrm{N} \text { was considered as } \\
\text { sulfammox only. }\end{array}$ & [30] \\
\hline $\begin{array}{l}\text { Upflow Anaerobic Sludge Blanket } \\
\text { Reactor } \\
\text { (UASBR) }\end{array}$ & $50-60$ & $210-240$ & 40 & 30 & $\begin{array}{l}\text { The reduction of } \mathrm{SO}_{4}^{2-} \text { and } \mathrm{NH}_{4}-\mathrm{N} \text { was considered as } \\
\text { sulfammox only. }\end{array}$ & {$[31]$} \\
\hline $\begin{array}{l}\text { Non-Woven Rotating Biological } \\
\text { Contactor } \\
\text { (NWRBC) }\end{array}$ & ca. 198 & ca. 528 & ca. 100 & ca. 70 & $\begin{array}{l}\text { The reduction of } \mathrm{SO}_{4}{ }^{2-} \text { and } \mathrm{NH}_{4}{ }_{4}^{+} \text {was considered as a } \\
\text { sulfammox only. }\end{array}$ & [9] \\
\hline $\begin{array}{l}\text { Anaerobic Attached-Growth } \\
\text { Bioreactor } \\
\text { (AAGB) }\end{array}$ & 50 & 57 & ca. 43 & ca. 59 & $\begin{array}{l}\text { The reduction of } \mathrm{SO}_{4}{ }^{2-} \text { and } \mathrm{NH}_{4}{ }_{4} \text { was considered as a } \\
\text { sulfammox only. }\end{array}$ & [23] \\
\hline
\end{tabular}


A study by Zhang et al. [10] investigated the effect of $\mathrm{NO}_{2}-\mathrm{N}$ on the anaerobic oxidation of $\mathrm{NH}_{4}-\mathrm{N}$. They showed that, with a combined decrease in concentration of $\mathrm{SO}_{4}{ }^{2-}$ from 216 to $100 \mathrm{mg} / \mathrm{dm}^{3}$, $\mathrm{NH}_{4}-\mathrm{N}$ from 183 to $80 \mathrm{mg} / \mathrm{dm}^{3}$ and $\mathrm{NO}_{2}-\mathrm{N}$ from 34 to $28 \mathrm{mg} / \mathrm{dm}^{3}$, the efficiency of $\mathrm{NH}_{4}-\mathrm{N}$ removal increased from $55 \%$ to $100 \%$. However, this study does not clearly show the influence of $\mathrm{SO}_{4}{ }^{2-}$ itself on the process. In our study, we decided to keep the $\mathrm{NH}_{4}-\mathrm{N}$ and $\mathrm{NO}_{2}-\mathrm{N}$ inflow to the reactors unchanged in order to determine the influence of $\mathrm{SO}_{4}{ }^{2-}$ on the process.

In $\mathrm{R} 1$, where the influent $\mathrm{SO}_{4}{ }^{2-}$ concentration was constant at $22 \mathrm{mg} \mathrm{SO}_{4}{ }^{2-} / \mathrm{dm}^{3}$, a gradual increase in the rates of AUR and SAA could be observed as well as their stabilization from day 49, as shown in Figure 2a. Comparing these values with the values in R2 in Figure 2b, it can be seen that, despite the approximately four-fold higher $\mathrm{SO}_{4}{ }^{2-}$ concentration in the effluents in $\mathrm{R} 2(90 \mathrm{mg}$ $\mathrm{SO}_{4}{ }^{2-} / \mathrm{dm}^{3}$ for R2), the AUR and SAA showed similar values from the beginning of the test to day 29 . The AUR increased from $1.3 \mathrm{mg} \mathrm{N} / \mathrm{g}$ VSS.h to $2.1 \mathrm{mg} \mathrm{N} / \mathrm{g}$ VSS.h (R1) and from $1.1 \mathrm{mg}$ N/g VSS.h to $2.1 \mathrm{mg} \mathrm{N} / \mathrm{g}$ VSS.h (R2), while the SAA increased from $4 \mathrm{mg} \mathrm{N} / \mathrm{g}$ VSS.h to $5.6 \mathrm{mg} \mathrm{N} / \mathrm{g}$ VSS.h (R1) and $3.7 \mathrm{mg} \mathrm{N} / \mathrm{g}$ VSS·h to $5.3 \mathrm{mg} \mathrm{N} / \mathrm{g}$ VSS·h (R2).

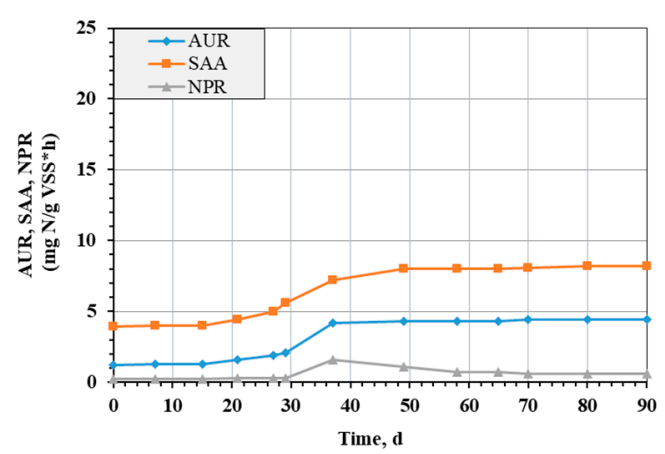

(a)

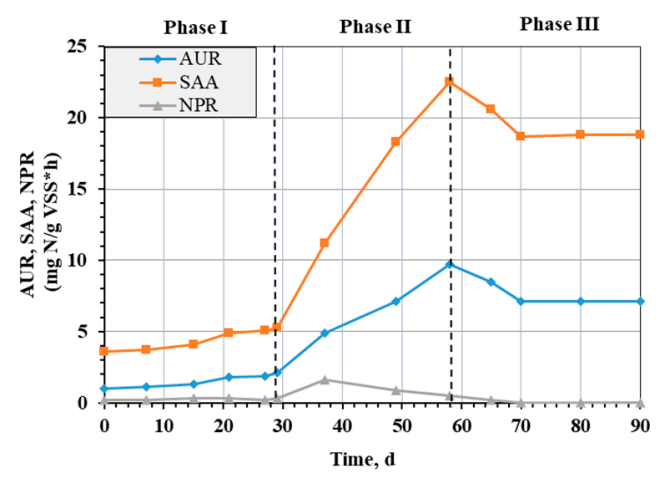

(b)

Figure 2. Ammonia utilization rate (AUR), specific annamox activity (SAA) and nitrate production rate (NPR) in R1 (a) and in R2 (b).

On day 37, there was a clear increase in AUR, SAA and NPR in R1. This showed that the efficiency of the anammox process was greatly improved as more $\mathrm{NH}_{4}-\mathrm{N}$ was oxidized with $\mathrm{NO}_{2}-\mathrm{N}$. The increase in NPR also confirmed that more $\mathrm{NH}_{4}-\mathrm{N}$ was oxidized as approximately $11 \%$ was converted to $\mathrm{NO}_{3}-\mathrm{N}$ in this process.

Near the end of the study, there was a stabilization of AUR values, SAA and a decrease in NPR in R1. AUR increased to a maximum of $4.4 \mathrm{mg} \mathrm{N} / \mathrm{g}$ VSS.h, and SAA increased to $8.1 \mathrm{mg} \mathrm{N} / \mathrm{g}$ VSS.h.

In $\mathrm{R} 2$, on day 37, the cycle time was reduced from $6 \mathrm{~h}$ to $3 \mathrm{~h}$, which resulted in the concentration of $\mathrm{SO}_{4}{ }^{2-}$ being twice as high as in the previous period: $-360 \mathrm{mg} / \mathrm{dm}^{3} \cdot \mathrm{d}$ and $180 \mathrm{mg} / \mathrm{dm}^{3} \cdot \mathrm{d}$ for phases II and I, respectively. This affected the AUR and SAA significantly, as can be seen in Figure 2b. This increase was evident throughout phase II. The AUR value at the end of this phase was $9.7 \mathrm{mg} \mathrm{N} / \mathrm{g}$ VSS.h, while SAA was $22.5 \mathrm{mg} \mathrm{N} / \mathrm{g}$ VSS.h. This confirmed the positive influence of $\mathrm{SO}_{4}{ }^{2-}$ on the course of the $\mathrm{NH}_{4}-\mathrm{N}$ oxidation process. $\mathrm{SO}_{4}{ }^{2-}$ seems to be an additional acceptor that improves the rate and efficiency of the process, increasing the efficiency of $\mathrm{NH}_{4}-\mathrm{N}$ removal as shown in Figure 3. 


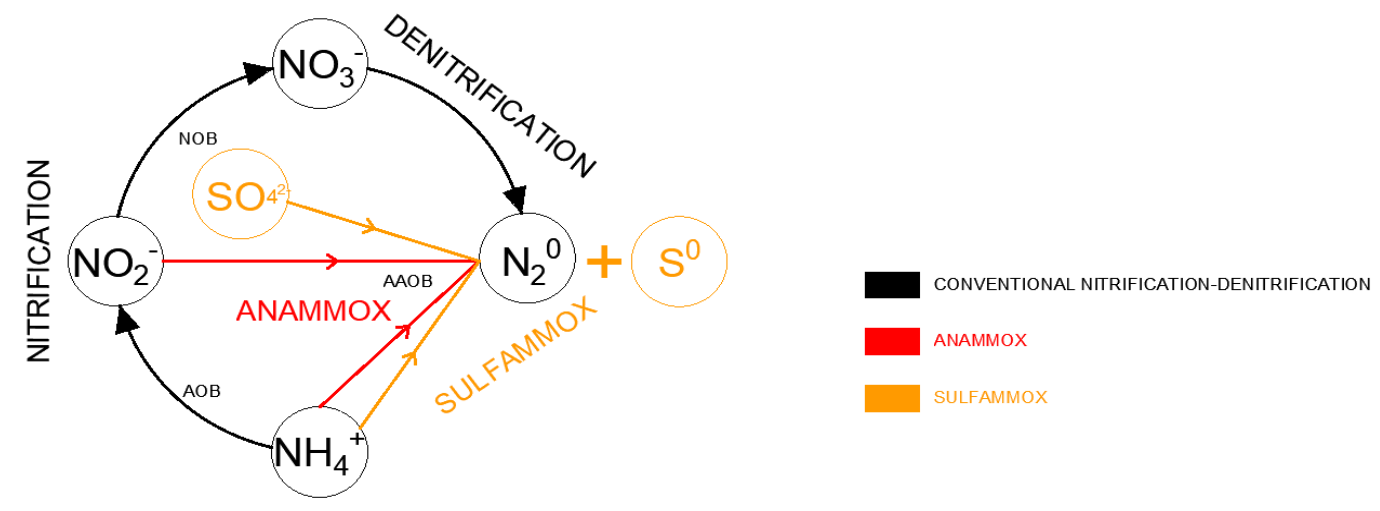

Figure 3. Diagram showing the coexistence of anammox and sulfammox processes.

There are reports in the literature confirming that $\mathrm{SO}_{4}{ }^{2-}$ can increase the total removal of $\mathrm{NH}_{4}-\mathrm{N}$. Liu et al. [9] noted in his research that the $\mathrm{NH}_{4}-\mathrm{N}$ removal rate was always higher than expected and the $\mathrm{NH}_{4}-\mathrm{N} / \mathrm{NO}_{2}-\mathrm{N}$ consumption ratio was about 1.1:1, which was much higher than previously reported [32]. It was then concluded that, due to large amounts of $\left(\mathrm{NH}_{4}\right)_{2} \mathrm{SO}_{4}$ in the feed, $\mathrm{SO}_{4}{ }^{2-}$ could be the source of the additional electron acceptor.

Moreover, Yang et al. [31] noted that as the concentration of $\mathrm{NH}_{4}-\mathrm{N}$ and $\mathrm{SO}_{4}{ }^{2-}$ increased, incrementally more of both were removed in their batch tests. When the $\mathrm{NH}_{4}-\mathrm{N}_{\text {and }} \mathrm{SO}_{4}{ }^{2-}$ concentrations in the inflow were approximately 28 and $76 \mathrm{mg} / \mathrm{dm}^{3}$, respectively, the removal efficiency was close to $0 \%$. However, when the average $\mathrm{NH}_{4}-\mathrm{N}_{\text {and }} \mathrm{SO}_{4}{ }^{2-}$ concentrations in the inflow increased to 92 and $307 \mathrm{mg} / \mathrm{dm}^{3}$, the removed amount decreased to 40 and $130 \mathrm{mg} / \mathrm{dm}^{3}$, respectively. Thus, high concentrations of $\mathrm{NH}_{4}-\mathrm{N}$ and $\mathrm{SO}_{4}{ }^{2-}$ may promote the simultaneous removal of these compounds, as shown in our research.

Phase III in R2 showed a downward trend in AUR and anammox rates from $9.7 \mathrm{mg} \mathrm{N} / \mathrm{g}$ VSS.h to $7.1 \mathrm{mg} \mathrm{N} / \mathrm{g}$ VSS·h and from $22.5 \mathrm{mg} \mathrm{N} / \mathrm{g}$ VSS.h to $18.7 \mathrm{mg} \mathrm{N} / \mathrm{g}$ VSS.h, respectively. This was due to the reduction of the $\mathrm{SO}_{4}{ }^{2-}$ concentration flowing into the reactor. Again, fewer electron acceptors, in the form of $\mathrm{SO}_{4}{ }^{2-}$, were present in the environment; therefore, the rate of $\mathrm{NH}_{4}-\mathrm{N}$ oxidation decreased because half as much $\mathrm{SO}_{4}{ }^{2-}$ flowed in per day. The tests were performed until the process stabilized, and constant values of AUR, SAA and NPR were achieved by the 90th day.

Moreover, Zhang et al. [20] noticed that, as the concentration of $\mathrm{SO}_{4}{ }^{2-}$ increased from about 90 $\mathrm{mg} / \mathrm{dm}^{3}$ to about $170 \mathrm{mg} / \mathrm{dm}^{3}$ and $\mathrm{NH}_{4}-\mathrm{N}$ from about $50 \mathrm{mg} / \mathrm{dm}^{3}$ to about $120 \mathrm{mg} / \mathrm{dm}^{3}$, the efficiency of $\mathrm{NH}_{4}-\mathrm{N}$ removal increased from $40 \%$ to $90 \%$. However, a further increase in the concentration of $\mathrm{SO}_{4}{ }^{2-}$ to about $360 \mathrm{mg} / \mathrm{dm}^{3}$ and $\mathrm{NH}_{4}-\mathrm{N}$ to about $180 \mathrm{mg} / \mathrm{dm}^{3}$ resulted in a decrease in $\mathrm{NH}_{4}-\mathrm{N}$ removal up to roughly 20\%. Similarly, in an Expanded Granular Sludge Bed Reactor (EGSBR) [21] under chemical oxygen demand (COD) conditions, the $\mathrm{NH}_{4}-\mathrm{N}$ removal efficiency gradually improved from $40-58 \%$ to $40-70 \%$ when the inflow $\mathrm{NH}_{4}-\mathrm{N}$ concentrations increased from 166-666 mg N/dm $\mathrm{do}^{3}$ to $1000-2000 \mathrm{mg}$ $\mathrm{N} / \mathrm{dm}^{3}$. Comparatively, after increasing the $\mathrm{NH}_{4}-\mathrm{N}$ concentration to $>3000 \mathrm{mg} \mathrm{N} / \mathrm{dm}^{3}$, the efficiency of $\mathrm{NH}_{4}-\mathrm{N}$ reduction decreased to approximately 10-25\%. This was due to the inhibition of the anammox process with free ammonia. This proves that an increase in $\mathrm{NH}_{4}-\mathrm{N}$ and $\mathrm{SO}_{4}{ }^{2-}$ concentrations improves the process of anaerobic $\mathrm{NH}_{4}-\mathrm{N}$ oxidation only to a certain extent. In our study, there was no inhibition of the process due to excessively high concentrations of these compounds.

Wu et al. [26] noted that they had achieved an $\mathrm{NH}_{4}-\mathrm{N}$ removal efficiency of $98 \%$, including $44 \%$ removed through sulfammox. Compounds containing $\mathrm{SO}_{4}{ }^{2-}$ can therefore effectively improve the efficiency of the anaerobic oxidation of $\mathrm{NH}_{4}-\mathrm{N}$, but at the same time, anaerobic conditions favor the decomposition of $\mathrm{SO}_{4}{ }^{2-}$ to $\mathrm{S}^{0}$, which is less toxic to the environment. The sulfammox process has so far been studied mainly as an independent process (without $\mathrm{NO}_{2}-\mathrm{N}$ addition). Moreover, there has been more interest in the influence of $\mathrm{NH}_{4}-\mathrm{N}$ concentration on the sulfammox process [21] and the N/S ratio [20] rather than directly considering the effect of $\mathrm{SO}_{4}{ }^{2-}$ itself. 
Bi et al. [11] challenged the sulfammox process and postulated that AAOBs did not have the ability to oxidize $\mathrm{NH}_{4}-\mathrm{N}$ using $\mathrm{SO}_{4}{ }^{2-}$ as an electron acceptor and that SRAO was a combination of aerobic ammonium oxidation, anammox and heterotrophic sulfate reduction processes. Moreover, the specification of the efficiency of $\mathrm{NH}_{4}-\mathrm{N}$ and $\mathrm{SO}_{4}{ }^{2-}$ removal in the sulfammox process does not reflect the course of the process as thoroughly as the AUR and the SAA, which the authors do not provide in their research.

\section{Conclusions}

In this study, it was shown that $\mathrm{SO}_{4}{ }^{2-}$ could be used as an additional electron acceptor in the anaerobic oxidation of $\mathrm{NH}_{4}-\mathrm{N}$. Along with the increased share of $\mathrm{SO}_{4}{ }^{2-}$, both AUR and SAA showed an increasing trend. In $\mathrm{R} 1$, where the concentration of $\mathrm{SO}_{4}{ }^{2-}$ in the inflow was constant at the level of $22 \mathrm{mg} \mathrm{SO}_{4}{ }^{2-} / \mathrm{dm}^{3}$, there was a gradual increase in the AUR and SAA indicators from $1.2 \mathrm{mg} \mathrm{N} / \mathrm{g} \mathrm{VSS} \cdot \mathrm{h}$ to $4.4 \mathrm{mg} \mathrm{N} / \mathrm{g}$ VSS.h and from $3.9 \mathrm{mg} \mathrm{N} / \mathrm{g}$ VSS.h to $8.2 \mathrm{mg} \mathrm{N} / \mathrm{g}$ VSS.h, respectively. In R2 in phase I, over a $6 \mathrm{~h}$ cycle, AUR and SAA increased from $1 \mathrm{mg} \mathrm{N} / \mathrm{g}$ VSS.h to $2.1 \mathrm{mg} \mathrm{N} / \mathrm{g}$ VSS.h and from $3.6 \mathrm{mg}$ $\mathrm{N} / \mathrm{g}$ VSS.h to $5.3 \mathrm{mg} \mathrm{N} / \mathrm{g}$ VSS.h; in phase II, over a $3 \mathrm{~h}$ cycle, they increased to $9.7 \mathrm{mg} \mathrm{N} / \mathrm{g}$ VSS.h and $22.5 \mathrm{mg} \mathrm{N} / \mathrm{g}$ VSS.h; and in phase III, over a $3 \mathrm{~h}$ cycle, they dropped to $7.1 \mathrm{mg} \mathrm{N} / \mathrm{g}$ VSS.h and $18.8 \mathrm{mg}$ $\mathrm{N} / \mathrm{g}$ VSS.h, respectively. It can therefore be concluded that $\mathrm{SO}_{4}{ }^{2-}$ contributes to the rate and efficiency of the anammox process. Further studies on the influence of the $\mathrm{NH}_{4}-\mathrm{N} / \mathrm{SO}_{4}{ }^{2-}$ ratio on the process and identification of the bacteria responsible for sulfammox are suggested.

Author Contributions: Conceptualization, D.G. and J.M.; methodology, J.M.; software, J.M.; validation, J.M.; formal analysis, J.M.; investigation, D.G.; resources, J.M.; data curation, J.M.; writing—original draft preparation, D.G.; writing-review and editing, J.M.; visualization, D.G.; supervision, J.M.; project administration, D.G.; funding acquisition, J.M. All authors have read and agreed to the published version of the manuscript.

Funding: This research was funded by Narodowe Centrum Nauki grant number 2019/03/X/ST10/01127.

Conflicts of Interest: The authors declare no conflict of interest.

\section{References}

1. Duyar, A.; Ozdemir, S.; Akman, D.; Akgul, V.; Sahinkaya, E.; Cirik, K. Optimization of sulfide-based autotrophic denitrification process in an anaerobic baffled reactor. J. Chem. Technol. Biotechnol. 2018, 93, 754-760. [CrossRef]

2. Liu, C.; Zhao, D.; Yan, L.; Wang, A.; Gu, Y.; Lee, D. Elemental sulfur formation and nitrogen removal from wastewaters by autotrophic denitrifiers and anammox bacteria. Bioresour. Technol. 2015, 191, 332-336. [CrossRef] [PubMed]

3. Sarti, A.; Pozzi, E.; Chinalia, F.A.; Ono, A.; Foresti, E. Microbial processes and bacterial populations associated to anaerobic treatment of sulfate-rich wastewater. Process Biochem. 2010, 45, 164-170. [CrossRef]

4. Wei, C.; Wang, W.; Deng, Z.; Wu, C. Characteristics of high-sulfate wastewater treatment by two-phase anaerobic digestion process with Jet-loop anaerobic fluidized bed. J. Environ. Sci. 2007, 19, 264-270. [CrossRef]

5. Sinbuathong, N.; Khaodhiar, S.; Liengcharernsit, W.; Sirirote, P.; Watts, D. Effect of sulfate on the methanogenic activity of a bacterial culture from a brewery wastewater during glucose degradation. J. Environ. Sci. 2007, 19, 1025-1027. [CrossRef]

6. Zhang, D.; Cui, L.; Zhu, H.; Madani, R.M.A.; Liang, J. Treatment performance and microbial community under ammonium sulphate wastewater in a sulphate reducing ammonium oxidation process. Environ. Technol. 2020. [CrossRef]

7. Fdz-Polanco, F.; Fdz-Polanco, M.; Fernandez, N.; Urueña, M.A.; Garcia, P.A.; Villaverde, S. New process for simultaneous removal of nitrogen and sulphur under anaerobic conditions. Water Res. 2001, 35, 1111-1114. [CrossRef]

8. Kartal, B.; van Niftrik, L.; Keltjens, J.T.; Op den Camp, H.J.M.; Jetten, M.S.M. Anammox-Growth Physiology, Cell Biology, and Metabolism. Adv. Microb. Physiol. 2012, 60, 211-262. 
9. Liu, S.; Yang, F.; Gong, Z.; Meng, F.; Chen, H.; Xue, Y.; Furukawa, K. Application of anaerobic ammonium-oxidizing consortium to achieve completely autotrophic ammonium and sulfate removal. Bioresour. Technol. 2008, 99, 6817-6825. [CrossRef] [PubMed]

10. In 't Zandt, M.H.; de Jong, A.E.; Slomp, C.P.; Jetten, M.S. The hunt for the most-wanted chemolithoautotrophic spookmicrobes. FEMS Microbiol. Ecol. 2018, 94, fiy064. [CrossRef] [PubMed]

11. Bi, Z.; Wanyan, D.; Li, X.; Huang, Y. Biological conversion pathways of sulfate reduction ammonium oxidation in anammox consortia. Front. Environ. Sci. Eng. 2020, 14, 38. [CrossRef]

12. Rikmann, E.; Zekker, I.; Tomingas, M.; Tenno, T.; Loorits, L.; Vabamäe, P.; Mandel, A.; Raudkivi, M.; Daija, L.; Kroon, K.; et al. Sulfate-reducing anammox for sulfate and nitrogen containing wastewaters. Desalin. Water Treat. 2016, 57, 3132-3141. [CrossRef]

13. Ali, M.; Okabe, S. Anammox-based technologies for nitrogen removal: Advances in process start-up and remaining issues. Chemosphere 2015, 141, 144-153. [CrossRef]

14. Klein, K.; Kattel, E.; Goi, A.; Kivi, A.; Dulova, N.; Saluste, A.; Zekker, I.; Trapido, M.; Tenno, T. Combined treatment of pyrogenic wastewater from oil shale retorting. Oil Shale 2017, 34, 82-96. [CrossRef]

15. Beller, H.R.; Chain, P.S.G.; Letain, T.E.; Chakicherla, A.; Larimer, F.W.; Richardson, P.M.; Coleman, M.A.; Wood, A.P.; Kelly, D.P. The genome sequence of the obligately chemolithoautotrophic, facultatively anaerobic bacterium Thiobacillus denitrificans. J. Bacteriol. 2006, 188, 1473-1488. [CrossRef]

16. Yu, H.; Wang, A.; Chen, C. Structure and dynamics of microbial community in the denitrifying sulfide removal process. Huanjing Kexue 2013, 34, 1190-1195. [PubMed]

17. Wang, X.; Sun, G.; Zhu, Y. Thermodynamic energy of anaerobic microbial redox reactions couples elemental biogeochemical cycles. J. Soils Sed. 2017, 17, 2831-2846. [CrossRef]

18. Di Capua, F.; Pirozzi, F.; Lens, P.N.L.; Esposito, G. Electron donors for autotrophic denitrification. Chem. Eng. J. 2019, 362, 922-937. [CrossRef]

19. Kosugi, Y.; Matsuura, N.; Liang, Q.; Yamamoto-Ikemoto, R. Nitrogen flow and microbial community in the anoxic reactor of "Sulfate Reduction, Denitrification/Anammox and Partial Nitrification" process. Biochem. Eng. J. 2019, 151, 107304. [CrossRef]

20. Zhang, D.; Cui, L.; Wang, H.; Liang, J. Study of sulfate-reducing ammonium oxidation process and its microbial community composition. Water Sci. Technol. 2019, 79, 137-144. [CrossRef]

21. Wang, D.; Liu, B.; Ding, X.; Sun, X.; Liang, Z.; Sheng, S.; Du, L. Performance evaluation and microbial community analysis of the function and fate of ammonia in a sulfate-reducing EGSB reactor. Appl. Microbiol. Biotechnol. 2017, 101, 7729-7739. [CrossRef]

22. Zhang, L.; Zheng, P.; He, Y.; Jin, R. Performance of sulfate-dependent anaerobic ammonium oxidation. Sci. China Ser. B 2009, 52, 86-92. [CrossRef]

23. Zhao, Q.I.; Li, W.; You, S.J. Simultaneous removal of ammonium-nitrogen and sulphate from wastewaters with an anaerobic attached-growth bioreactor. Water Sci. Technol. 2006, 54, 27-35. [CrossRef] [PubMed]

24. Rikmann, E.; Zekker, I.; Tomingas, M.; Tenno, T.; Menert, A.; Loorits, L.; Tenno, T. Sulfate-reducing anaerobic ammonium oxidation as a potential treatment method for high nitrogen-content wastewater. Biodegradation 2012, 23, 509-524. [CrossRef]

25. Zhang, D.; Cui, L.; Madani, R.M.A.; Wang, H.; Zhu, H.; Liang, J. Effect of nitrite and nitrate on sulfate reducing ammonium oxidation. Water Sci. Technol. 2019, 80, 634-643. [CrossRef]

26. Wu, L.; Yan, Z.; Li, J.; Huang, S.; Li, Z.; Shen, M.; Peng, Y. Low temperature advanced nitrogen and sulfate removal from landfill leachate by nitrite-anammox and sulfate-anammox. Environ. Pollut. 2020, 259, 113763. [CrossRef]

27. Dapena-Mora, A.; Arrojo, B.; Campos, J.L.; Mosquera-Corral, A.; Méndez, R. Improvement of the settling properties of Anammox sludge in an SBR. J. Chem. Technol. Biotechnol. 2004, 79, 1417-1420. [CrossRef]

28. Greenberg, A.E.; Clesceri, L.S.; Eaton, A.D. APHA Standard Methods for the Examination of Water and Waste Water, 21st ed.; American Public Health Association, American Water Works Association, Water Pollution Control Federation: Washington, DC, USA, 2005.

29. Prachakittikul, P.; Wantawin, C.; Noophan, P.; Boonapatcharoen, N. ANAMMOX-like performances for nitrogen removal from ammonium-sulfate-rich wastewater in an anaerobic sequencing batch reactor. $J$. Environ. Sci. Health 2016, 51, 220-228. [CrossRef]

30. Cai, J.; Jiang, J.X.; Zheng, P. Isolation and identification of bacteria responsible for simultaneous anaerobic ammonium and sulfate removal. Sci. China Chem. 2010, 53, 645-650. [CrossRef] 
31. Yang, Z.; Zhou, S.; Sun, Y. Start-up of simultaneous removal of ammonium and sulfate from an anaerobic ammonium oxidation (anammox) process in an anaerobic up-flow bioreactor. J. Hazard. Mater. 2009, 169, 113-118. [CrossRef] [PubMed]

32. Van De Graaf, A.A.; De Bruijn, P.; Robertson, L.A.; Jetten, M.S.M.; Kuenen, J.G. Autotrophic growth of anaerobic ammonium-oxidizing micro-organisms in a fluidized bed reactor. Microbiology 1996, 142, 2187-2196. [CrossRef]

Publisher's Note: MDPI stays neutral with regard to jurisdictional claims in published maps and institutional affiliations.

(C) 2020 by the authors. Licensee MDPI, Basel, Switzerland. This article is an open access article distributed under the terms and conditions of the Creative Commons Attribution (CC BY) license (http://creativecommons.org/licenses/by/4.0/). 